\title{
CASE REPORT ON SYMPTOMATIC HYPOCALCEMIA ASSOCIATED WITH ACUTE SEVERE MALARIA - NEED FOR VIGILANCE
}

${ }^{1}$ Akinyele Akinlade, ${ }^{2}$ Michael Olamoyegun, ${ }^{3}$ Ofem Enang

${ }^{1}$ Genera; Hospital Odan, Lagos; ${ }^{2}$ Ladoke Akintola University Teaching Hospital Ogbomosho, Oyo State; ${ }^{3}$ University of Calabar Teaching Hospital Calabar, Cross River State

\section{BACKGROUND}

The commonest cause of hypocalcemia is hypoalbuminemia and its presentation varies widely, from asymptomatic to life-threatening situations. Hypocalcemia is frequently encountered in patients who are hospitalized. Depending on the cause, unrecognized or poorly treated hypocalcemic emergencies can lead to significant morbidity or death

Total calcium -1.37 (2.1 2.5) $\mathrm{mmol} / \mathrm{L}$ (at admission)

Total Calcium - 1.8 (2.1 2.5) $\mathrm{mmol} / \mathrm{L}$ (next day after Ca gluconate infusion) Total Calcium - $2.16(2.12 .6) \mathrm{mmol} / \mathrm{L}$ (5 $\left.5^{\text {th }} \mathrm{DOA}\right)$

Corrected calcium 2.34 (2.1 2.6) $\mathrm{mmol} / \mathrm{L}$ $\left(5^{\text {th }} \mathrm{DOA}\right)$

Albumin 30.05 (35 50) g/L

Phosphate $1.89(1.0$ 1.5) $\mathrm{mmol} / \mathrm{L}$

Electrolytes - normal

Urea $2.13(2.58 .0) \mathrm{mmol} / \mathrm{L}$

\section{CASE}

A 25 year-old Polytechnic student who presented at the emergency department with a 5-day history of high grade fever $\left(39.2^{\circ} \mathrm{C}\right)$ with chills and rigor, generalized body weakness, postpandrial vomiting, epigastic pain and passage of melena and feeling of cramps in her hands and feet. Has no history of PUD but had used NSAIDS for pains and the cramps.

Her RBS was $155 \mathrm{mg} / \mathrm{dl}$. Genotype unknown. Pregnancy was excluded.

Her clinical examination showed an acutely ill-looking, febrile $\left(\mathrm{T} 39.2^{\circ} \mathrm{C}\right.$ ), not pale, anicteric, nil pedal edema, demonstrable carpopedal spasms

$\mathrm{P} 84 /$ min irregular, normal volume

BP $133 / 103 \mathrm{mmHg}$, by next day $111 / 81 \mathrm{mmHg}$

\section{RESULTS}

Creatinine 80.48 (45 110) umol/L

Magnesium $0.86(0.71 .15) \mathrm{mmol} / \mathrm{L}$

Phosphate $0.97(0.81 .4) \mathrm{mmol} / \mathrm{L}\left(5^{\text {th }} \mathrm{DOA}\right)$

PTH 38.6 ()pg/ml

TFT normal

Abdominal and Neck USS No parathyroid enlargement and no abdominal abnormality CBC $\mathrm{Hb} 12.7 \mathrm{~g} / \mathrm{dl}$, low $\mathrm{MCV}$ and $\mathrm{MCH}$. Normal WBC

ECG findings Sinus rhythm, APCs, prolonged QTC

\section{MANAGEMENT}

She was treated as a case of acute severe malaria with hypocalcemic tetany and upper $\mathrm{Gl}$ bleeding

She got better with $10 \%$ calcium gluconate infusion, antimalarial and parenteral rabeprazole. Was discharged on the $5^{\text {th }}$ DOA to MOPD for follow up on oral calcium supplements and rabeprazole

\section{CONCLUSION}

A high index of suspicious is necessary in order not to miss the diagnosis of hypocalcemia, particularly if it presents with an unrelated medical illness such as malaria fever 